\title{
FORMAÇÃO OU REIFICAÇÃO? A EDUCAÇÃO ENTRE O MESMO E O OUTRO
}

\author{
AMARILDo LUIZ TREVISAN*
}

\begin{abstract}
RESUMO: O artigo propõe discutir em que medida a categoria da reificação pode auxiliar a educação na leitura dos processos de estetização do mundo da vida. No giro da formação cultural, a dialética colocara o indivíduo, ou o em si, em contraposição com o mundo, num processo de alienação ou de estranhamento com o outro que conduzia à progressão gradativa do espírito em direção a um reino de mais liberdade. Marx subverte a relação ao dizer que a reificação ocorre no sentido contrário, isto é, na materialidade do trabalho alienado que transforma regressivamente o sujeito em algo sempre igual, em objeto, em coisa, isto é, no mesmo. A educação, ao avaliar as contribuições da cultura visual, também ficou dividida entre considerar se, de fato, ela representa a assunção do mesmo ou do outro, o vivo ou morto. Cabe analisar se a realização de uma leitura dos processos de estetização do ponto de vista desta categoria, compreendida no sentido hermenêutico, possibilita então uma saída deste impasse.
\end{abstract}

Palavras-chave: Estetização. Reificação e formação.

\section{TRAINING OR REIFICATION? \\ EDUCATION BETWEEN THE SAME AND THE OTHER}

ABSTRACT: This paper discusses to what extent reification can help education seize the aesthetization processes of the world of life. In the course of cultural training, dialectics has opposed the individual or self to the world. This process of alienation or estrangement from the other was leading to a gradual advance of the spirit towards a kingdom of greater freedom. Marx subverted this relation when he said reification occurred in the opposite direction, that is, the materiality of alienated labor regressively transformed the subject in something always equal, in an object, in a thing, in the same. When it evaluated the contributions of visual culture, education also got divided: does it in fact represents the assumption of the same or the other, the living or the dead. It is worth analyzing whether a reading of these aesthetization processes from this category point of view, here understood in the hermeneutic sense, provides a way out of this dead-end.

Key words: Aesthetization. Reification. Formation.

Doutor em Educação e professor associado do Programa de Pós-Graduação em Educação da Universidade Federal de Santa Maria (UfSM). E-mail: amarildoluiz@terra.com.br 


\title{
Formation OU RÉIFICATION? \\ L'ÉDUCATION ENTRE LE MÊME ET L'AUTRE
}

\begin{abstract}
RÉSUMÉ: Cet article propose de discuter dans quelle mesure la catégorie de la réification peut aider l'éducation dans la lecture des processus d'esthétisation du monde de la vie. Au cours de la formation culturelle, la dialectique avait placé l'individu, ou le "en soi", comme opposé au monde, en un processus d'aliénation ou d'étrangeté envers l'autre qui conduisait à la progression graduelle de l'esprit vers un royaume de plus de liberté. Marx a subverti ce rapport en disant que la réification prend place en sens contraire, soit que la matérialité du travail aliéné transforme régressivement le sujet en quelque chose de toujours égal, en objet, en chose, c'est-à-dire, en même. Quand elle a évalué les contributions de la culture visuelle, l'éducation s'est également vue divisée entre la considération de savoir si en fait elle représente l'assomption du même ou de l'autre, du vivant ou du mort. Il convient d'analyser si une lecture des processus d'esthétisation du point de vue de cette catégorie, comprise au sens herméneutique, permet alors une sortie de cette impasse.
\end{abstract}

Mots-clés: Esthétisation. Réification. Formation.

\section{Considerações iniciais}

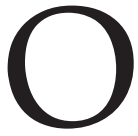

texto a seguir discute os processos de estetização do mundo da vida a partir do ângulo de análise do conceito de reificação, notadamente para auxiliar nos procedimentos de leitura e decodificação dessa cultura. $\mathrm{O}$ tratamento do assunto ocorre, de forma geral, contra o pano de fundo da dialética da formação cultural (Bildung) hegeliana. Porém, assim como procede Gadamer (1996) com relação à hermenêutica do conceito de formação, ao romper com o absoluto hegeliano, paulatinamente também a ideia da reificação vai se afastando dos seus vínculos de base, para se tornar um auxílio efetivo no entendimento dos processos de reprodução da cultura.

A intenção do trabalho é enfocar o tema, promovendo, inicialmente, uma breve exposição sobre o contexto da cultura atual para situar o diagnóstico da reificação. A seguir, é retomada sucintamente a sua origem no marxismo, em contraposição ao movimento da formação cultural (Bildung) hegeliana. E, por último, extraem-se algumas pistas deixadas no tratamento do assunto para repensar a interpretação da cultura. Afinal, também a educação, ao avaliar as contribuições da cultura visual, ficou dividida entre considerar se, de fato, ela representa a assunção do mesmo ou do outro, o vivo ou o morto. Cabe avaliar se a realização de uma leitura dos processos de estetização do ponto de vista desta categoria, compreendida no sentido hermenêutico, possibilita então uma saída deste imbroglio. 


\title{
A educação nos processos de estetização
}

No filme Escritores da liberdade (Freedom writers ${ }^{1}$ ) há um momento em que a professora, falando sobre a tradição clássica grega, cita Homero e é imediatamente interpelada por um aluno se ela não estaria se referindo ao personagem Homer, de Os Simpsons. Mesmo com toda sua boa vontade de iniciante, a professora nega, num primeiro momento, existir qualquer correlação entre o clássico/erudito e a cultura de massa. Sem dúvida, esta passagem do filme é bem ilustrativa da difícil tarefa de realizar educação no contexto dos processos de estetização do cotidiano, na medida em que a tendência é ver o outro da formação cultural como o mesmo da indústria cultural. Porém, em tese, a educação deveria ser um terreno propício para estabelecer uma comunicação crítica entre ambos os contextos, uma vez que os alunos chegam à escola contagiados pela cultura de massa divulgada cotidianamente pelos novos mídias. Esta situação leva a questionar o porquê de tal vínculo encontrar-se cindido na educação e qual é o fundamento, em sua formação, que fez a professora negar de início tal aproximação? Além disso, como fazer então a transição do conhecimento elaborado para o cotidiano, se tal ambiente já se encontra completamente impregnado de meias informações e verdades sobre todos os tipos de assunto? É possível que essa demanda não fique restrita aos simples mecanismos de alfabetização visual? Enfim, os processos de estetização representam uma ameaça ou possibilidade de redenção do elemento formativo da cultura?

Primeiramente, é preciso esclarecer que uma das principais características dessa nova forma de conhecimento é o fato de ela não estar presa na alta cultura, mas mesclada nos valores do cotidiano, os quais são intensificados pelos meios de comunicação e difundidos nos produtos da publicidade. Essa intensificação ou saturação vem preencher aquilo que, segundo Evangelista (2008, p. 12), estaria levando ao esvaziamento da razão humana:

\begin{abstract}
A capacidade de representação da razão humana estaria se esvaziando. Estaríamos diante do predomínio de um princípio esvaziador que atuaria em todas as esferas do mundo e da sociedade moderna, envolvendo suas instituições e suas formas simbólicas e imaginárias. Assim, por exemplo, estariam se processando a desreferencialização do real, a desmaterialização da economia, a desestetização da arte, a desconstrução da filosofia, a despolitização da sociedade e a dessubstancialização do sujeito. Ou seja, tudo o que existe estaria marcado pela efemeridade, pela fragmentação, pelo descentramento, pela indeterminação, pela descontinuidade, pelo ecletismo das diferenças e pelo caos paradoxal.
\end{abstract}

Entretanto, de acordo com Welsh (1995), a saturação do estético ocorre com o objetivo de criar uma "sociedade das emoções". Ele acredita que, em nome das emoções, as sociedades industriais avançadas tentam criar um "cenário hiperestético", 
o qual altera a percepção sensorial do indivíduo frente à realidade. Se essa tentativa fosse bem sucedida, no limite: "O mundo então se transformaria num espaço de emoções, e a sociedade numa sociedade de emoções" (p. 8). Sendo assim, o diagnóstico gerado por esse estado de coisas - de apagamento das fronteiras entre arte e vida e a transformação da realidade em imagens - aponta para o fato de que vivemos hoje um processo, para alguns de caráter irrevogável, de estetização do mundo da vida ou do cotidiano (Welsch, 1995 e 2001).

Um entendimento melhor dessa cultura passa pela classificação efetuada por Featherstone (1995), na obra Cultura de consumo e pós-modernismo. Ele distingue três formas específicas de ocorrência destes processos: o projeto das subculturas artísticas, produtor dos movimentos dadaísta, surrealista e da vanguarda histórica; o projeto de transformação da vida numa obra de arte, que fascinou muitos aspirantes e os próprios artistas e intelectuais, como Oscar Wilde, Richard Rorty e Foucault; e, por último, a preocupação com o fluxo veloz de signos e imagens que produzem a saturação do cotidiano, seguindo a análise da teoria do fetichismo da mercadoria de Marx, desenvolvida por Lukács, a Escola de Frankfurt e Jameson, entre outros.

De ora em diante, vou me concentrar neste terceiro momento de definição de estetização, dado que o fetichismo prepara, de certo modo, na obra de Marx, o surgimento da categoria da reificação. Ambos os conceitos estão muito próximos, pois o fetichismo seria o ocultamento das relações humanas numa relação entre coisas, ao passo que, de acordo com Bottomore (1988, p. 314), reificação significa

(...) a transformação dos seres humanos em seres semelhantes a coisas, que não se comportam de forma humana, mas de acordo com as leis do mundo das coisas. A reificação é um "caso especial" de alienação, sua forma mais radical e generalizada, característica da moderna sociedade capitalista.

Em resumo, segundo as palavras do próprio Marx (1983, p. 71), trata-se de "relações coisais entre pessoas e relações sociais entre coisas". Para trazer a lume mais alguns elementos analíticos, com o intuito de auxiliar na compreensão dessa categoria, é preciso traçar um pequeno esboço histórico de sua origem no marxismo.

\section{A reificação no panorama da formação cultural}

Embora Hegel fale em seus escritos de uma "razão observadora" (Bottomore, 1988, p. 314), o aparecimento do conceito de reificação se deu mais precisamente a partir da inversão dialética da fenomenologia do espírito por Karl Marx. Como é sabido, em traços largos no giro da formação cultural (Bildung), a dialética coloca o indivíduo, ou o em si, em contraposição com o mundo, ou com o outro, num processo de alienação e estranhamento que resultava, ao fim e ao cabo, no retorno 
ao para si. Essa ascese conduz à progressão gradativa do espírito em direção a um reino de mais liberdade. Porém, Marx subverte essa relação, dizendo que a dialética em Hegel está de ponta-cabeça e que seria necessário, para dar conta da análise do real, colocá-la novamente em pé. Desse modo, enquanto na fenomenologia do espírito o sujeito se lança no real e, contrapondo-se à objetividade, acaba recuperando a si mesmo nesse processo, na coisificação quem tem o controle são as condições sociais objetivas que se impõem à subjetividade. A dialética da formação ocorre no nível progressivo, "espiritual”, de engrandecimento do espírito ou da consciência, enquanto a reificação acontece no sentido contrário, isto é, na materialidade do trabalho alienado que transforma regressivamente o sujeito em objeto, isto é, em coisa. Talvez por esse motivo, no Manifesto comunista, Marx e Engels mostram desconfiança com a formação cultural, ao comentar: "A cultura (Bildung) cuja perda o burguês tanto lastima é para a imensa maioria apenas um adestramento para agir como máquina" (1993, p. 83). Em síntese, embora nascida no seio da formação cultural alemã, a teoria da reificação se opõe dialeticamente à formação cultural alemã, na famosa inversão produzida por Karl Marx no pensamento de Hegel. É justamente essa inversão, entre o elemento espiritual e o material, vivo e morto, que se torna chave para entender o sentido do conceito de coisificação.

Contudo, mesmo surgindo em contradição à manifestação cultural do espírito, é precisamente nesse terreno que, aos poucos, a categoria da reificação vai-se fazendo valer como metodologia produtiva de análise. Em História e consciência de classe, Lukács (2003, p. 222) estende essa lógica para a compreensão de algumas manifestações desse gênero, como a profissão do jornalista:

E o virtuose especialista, o vendedor de suas faculdades espirituais objetivas e coisificadas, não somente se torna um espectador do devir social (não é possível indicar aqui, mesmo que alusivamente, o quanto a administração e a jurisprudência modernas revestem, em oposição ao artesanato, os caracteres já evocados da fábrica), mas também assume uma atitude contemplativa em relação ao funcionamento de suas próprias faculdades objetivadas e coisificadas. Essa estrutura mostra-se em seus traços mais grotescos no jornalismo, em que justamente a própria subjetividade, o saber, o temperamento e a faculdade de expressão tornam-se um mecanismo abstrato, independente tanto da personalidade do "proprietário" como da essência material e concreta dos objetos em questão, e que é colocado em movimento segundo leis próprias. A "ausência de convicção" dos jornalistas, a prostituição de suas experiências e convicções só pode ser compreendida como ponto culminante da reificação capitalista.

O jogo de linguagem das categorias mortas não é casual nesta citação: expectador, contemplativo, mecanismo abstrato, independente, ausência de convicção, coisificadas, prostituição e reificação querem traduzir o cotidiano massificado ou mortificado de uma profissão afeita à produção cultural. É evidente que aqui também se afirma, em certo sentido, a imagem de que essa situação contraria a ideia da formação cultural, como se o relógio da história andasse de maneira invertida. $\mathrm{O}$ 
jornalista paga uma dívida constante com o funcionamento da racionalidade dominante no sistema, ao abrir mão de suas convicções e inclinações pessoais, e também da infinita diversidade do real que descreve, repassando ao leitor uma visão padronizada ou uniformizada da sociedade e do mundo. Se a formação cultural eleva o espírito humano para transcender as suas limitações, a coisificação seria o movimento que o diminui, absorvendo-lhe a moeda de troca da mercadoria, que acaba degradando as suas qualidades. A coisificação se impõe de fora para dentro e molda o indivíduo, inclusive as suas faculdades psíquicas e sensoriais, limitando a sua compreensão do existente. É como afirma Nobre (2008, p. 285), a partir de Lukács: “a reificação é justamente a maneira pela qual os agentes da produção capitalista experimentam a imposição pelo sistema do papel de portadores". No caso do jornalismo, ela opera na imposição da espetacularização do cotidiano com notícias seletivamente recortadas, dando ênfase a assaltos, mortes, sequestros, e, ao estimular o grotesco, promove o embrutecimento e a regressão do espírito, não a sua emancipação. ${ }^{2}$

\section{Reificação no estágio atual de discussão da cultura}

Comentando essa mesma passagem do livro de Lukács, Adorno (1993) diz, no aforisma 147 do Mínima moralia, que a reificação opera como perda progressiva da diferenciação. Para ele, a formação adquire um sentido mais amplo do que o puro giro do espírito sobre si mesmo, conforme previa o sistema hegeliano. Ela está cristalizada numa formação social determinada que, para sua autoconservação, acaba se impondo sobre a vida, danificando-a. Por isso, "a autoconservação anula a vida na subjetividade", sendo possível entender aqui os esforços de "adaptação" e "conformismo" da psicologia social e da antropologia cultural como "epifenômenos" (p. 201). Mesmo o que se distingue da técnica, e a própria diferenciação psicológica surgida com a especialização do trabalho, não consegue fugir dessa lógica, mas passa a "lubrificar" e alimentar o modo de produção. E é nesse quadro que ele entende a crítica de Lukács aos jornalistas, concluindo este raciocínio ao dizer que "a conservação de si perde seu si" (ibid., p. 202). Em outras palavras, perder "seu si" significa que o caminho do conhecimento e da racionalidade que, em princípio, poderia captar a realidade de maneira plural, rica de significados, acaba se perdendo em prol de uma visão voltada para aquilo que Chauí (2006) classifica de "mercado da moda". Com a imposição da realidade social objetiva, a formação social acaba "formando" ou moldando a subjetividade, tornando o plano da racionalidade não mais uma instância confiável. A saída para Adorno, então, estaria na arte, pois ela não é simples conhecimento, identidade com a coisa, mas "mímesis" ou transfiguração do real. A mímesis evidencia que a motivação utópica não está suspensa, mesmo no predomínio da universalização dos valores de troca. 
Em seu livro Reificación: un estudio en la Teoría del Reconocimiento, Axel Honneth (2007) defende a tese de que Lukács estaria, nesta citação, querendo minimamente dar um exemplo mais preciso de como está estruturada tal autorreificação, isto é, como autoconhecimento, visto na tentativa do jornalista de adaptar sua própria subjetividade, temperamento e habilidade de expressão aos interesses do suposto leitor em cada caso. Nesse sentido, ele interpreta a tese da reificação dentro da perspectiva intersubjetiva, a qual Lukács teria deixado de lado logo de saída em sua obra. As relações fraternas, intersubjetivas ou autênticas, isto é, o terreno da práxis, foram postergadas pelo teórico marxista em prol das relações imediatas, que estão acontecendo na reificação cotidiana. Esse projeto abandonado por Lukács serve para Honneth retomar a perspectiva da reificação como ponto de partida interpretativo, portanto. Ele busca assim uma reatualização do conceito a partir de Lukács, constatando que tal categoria fora transformada pelo capitalismo numa "segunda natureza" (Honneth, 2007, p. 27). Além disso, ela se caracterizaria por ser uma "conduta simplesmente observadora", uma "maneira indolente e desapaixonada" com "qualidade de coisa" (idem, ibid., p. 30), enfim uma atitude neutra frente à vida em geral, o ser humano, o entorno e seus problemas. Juntamente com o tratamento dessa categoria, Honneth leva adiante também a ideia de reconhecimento do outro, presente embrionariamente na dialética do senhor e do escravo, de Hegel. Busca ainda evidências em diversos autores (o "compromisso prático", em Dewey, a ideia de "cuidado", em Heidegger, e a "implicação" em Lukács) e mesmo na prática existencial, para mostrar que existem saídas para o comportamento alienado, pois a reificação seria, na sua interpretação, nada mais do que o "esquecimento do reconhecimento". É o reconhecimento prévio, subjacente ao plano do conhecimento, que determina a implicação mútua. E, como procura deixar claro a partir de Heidegger, ela pode estar muito mais ao "alcance da mão" do que "diante dos olhos" (Honneth, op. cit., p. 45-46). Essa outra perspectiva contraria o espírito de vazio e pessimismo deixados no rastro do tratamento dessa categoria por diversos autores. "Nesse sentido", como ele mesmo afirma, "uma postura de reconhecimento é expressão da valoração do significado qualitativo que possuem outras pessoas ou coisas para a realização de nossa existência" (p. 55-56).

Ao transportar tal ideia para o plano da relação do indivíduo consigo mesmo, Honneth percebe que essa atitude "não pode ser apenas a do conhecer, tampouco a relação consigo mesmo não pode se ater a estados mentais" (op. cit., p. 115). Na dimensão da autorreificação, conforme exposto no caso do jornalismo, teríamos um típico exemplo de esquecimento de si mesmo ou de desatenção consigo próprio. Reificação seria também uma atitude detetivesca ou construtivista consigo mesmo, na qual se substitui a atitude do reconhecimento por um conhecer objetivador. A crítica de Honneth a Lukács é que a categoria da reificação ainda ficou restrita à dimensão econômica, presa, portanto, ao funcionamento das "leis de mercado". Não 
foi percebida por ele "uma série de intentos de explicação do racismo ou da representação pornográfica das mulheres em conformidade com um padrão de este desenho" (ibid., p. 141). O formato do desenho sugerido por Honneth estaria situado no nível não epistêmico, não no plano do conhecimento, mas do reconhecimento, portanto no nível ontológico. Enfim, a abordagem que Lukács oferece ao conceito de reificação ainda se mantém prisioneira do "paradigma" economicista, fato este que o impede de ver o alcance "prático-social" embutido neste conceito.

Se, para Lukács, o nível mais elevado da reificação se encontra no jornalismo, nessa mesma direção Jameson (1995) diz, no artigo Reificação e utopia na cultura de massa, concordando também com Debord, que a imagem se tornou a forma última da mercadoria. Ele promove aí uma análise das manifestações culturais reificadas da sociedade capitalista em sua etapa multinacional. Nesse contexto, os indivíduos se relacionam primeiro com o universo das imagens, o qual, para ele, é o universo do cultural, para só depois tomarem contato propriamente com o produto. Esse relacionamento com a imagem é o que prende o sujeito à teia do consumo, tornando-o incapaz de transcender tal nível de objetividade. Jameson compartilha assim com as análises marxistas, inclusive as de Adorno, ao dizer que "a reificação ou a materialização constituem um traço estrutural chave tanto do modernismo como da cultura de massa" (1995, p. 17). Afinal, o modernismo passa por essa mesma situação, na medida em que, ainda segundo sua leitura de Adorno, a reificação adentrou a estrutura da obra de arte, enquanto a cultura de massa já está, pela sua própria dependência absoluta do mercado, completamente administrada. Decifrar esse traço passa por uma tentativa de ler a materialização que está oculta ou adormecida nos produtos da cultura. Jameson conclui pela necessidade de não separar alta e baixa culturas, afinal: "Tal aproximação exige que se leia a alta cultura e a cultura de massa interdependentes, como formas gêmeas e inseparáveis da fissão da produção estética sob o capitalismo" (op. cit., p. 14). Para exemplificar esta tese, ele analisa, nesse mesmo artigo, os filmes Tubarão, de Steven Spielberg (1975), e as duas partes de O poderoso chefão, de Francis Ford Coppola (1972 e 1974). Procura mostrar que, mesmo sendo produtos da cultura de massa, conseguem a suspensão das noções de tempo e espaço, produzindo assim a sensação de utopia, algo que se julgava privilégio apenas da grande obra de arte.

A partir destas breves considerações, percebe-se que a reificação não só acaba com as ideias de diferenciação ou de identidade própria (Adorno), de atenção com respeito a si mesmo, de implicação ou reconhecimento do outro e do mundo circundante (Honneth), mas ela serve também de fonte privilegiada de leitura do cultural (Jameson). Nela encontram-se pistas para auxiliar, de certo modo, a leitura da alta e da baixa cultura como formas interligadas. A transformação da própria mercadoria em imagem, no momento em que o dado espiritual se adapta aos impulsos 
econômicos, paradoxalmente coloca em contato novamente as duas pontas da dialética antes rompida com a crítica de Marx a Hegel. O giro da reificação não é incompatível, em princípio, com a leitura da formação hermenêutica, mas talvez o seu avesso, como uma dialética esquecida entre o mesmo e o outro. No próximo item, procurarei desenvolver melhor a tese de que a reificação se aproxima das exigências de uma investigação hermenêutica e que, nesse sentido, elas podem vir a se complementar. A retomada dessa discussão de maneira sintética visa servir aos propósitos da reflexão, procurando relacionar cada passo da formação hermenêutica à ideia de reificação.

\section{Formação ou reificação: duas pontas da mesma dialética?}

Em Verdade e método II, mais precisamente no item "Sobre o círculo da compreensão", Gadamer (1994) fragmenta a dialética hegeliana da formação do espírito na imanência. Depois de se desfazer da ideia do absoluto hegeliano, ${ }^{3}$ ele situa a interpretação na dependência do intérprete, na sua capacidade de fazer a costura entre cada um dos seus elementos constitutivos.

Para Gadamer (op. cit.), toda interpretação hermenêutica deve iniciar com a explicitação da expectativa de sentido: "A antecipação de sentido, que envolve o todo, se faz compreensão explícita quando as partes que se definem desde o todo acabam também definindo esse mesmo todo" (p. 63). Sendo assim, em linhas gerais a hermenêutica procura, num primeiro momento, fazer a relação da parte com o todo, o que implica colocar o texto dentro do contexto e vice-versa. Evidenciada nesse ponto da reflexão, a teoria da reificação, como possibilidade de leitura dos processos de estetização, demonstra a sua produtividade porque permite não apenas uma leitura instrucional das imagens. Embora possamos discordar de seu exame crítico do real, não se pode negar que ela atende à expectativa ontológica de tomada de posição frente ao mundo, isto é, possibilita uma visão de conjunto ou de totalidade. Para ela, não basta a leitura de imagens simplesmente, mas é necessária uma tomada de posição mais abrangente, isto é, cultivar uma preocupação mais ampliada com os destinos do mundo comum, relacionando a parte com o todo. Caso contrário, a reflexão ficaria aprisiona ao nível do conhecimento empírico, exposta à obrigatoriedade de decifrar imagem por imagem, signo por signo, numa busca frenética de explicação dos processos de estetização de maneira singularizada, sem referenciais mais profundos de análise.

A seguir, a hermenêutica propõe em sua abordagem encontrar um ponto médio, ou seja, buscar um ponto desencadeador da interpretação. No caso da análise da categoria de reificação, creio que esse item fica explícito no momento em que Lukács critica a linguagem utilizada no jornalismo. O ponto médio pode ser percebido no 
sentido de que o caminho do conhecimento ou da racionalidade cognitivo-instrumental está fechado e de que é necessário buscar novas saídas, conforme demonstram autores que analisaram posteriormente esta questão, como Adorno, Honneth e Jameson. O próximo elemento proposto pela hermenêutica requer a revisão dos preconceitos. E isso quer dizer: avaliar as opiniões prévias já consolidadas sobre o assunto, a fim de torná-las explícitas, para não desvirtuar o processo interpretativo. É preciso esclarecer que a hermenêutica de Gadamer admite que o preconceito seja uma instância pré-reflexiva anterior ao plano racional, e que ele também determina em geral a nossa pré-compreensão das coisas. O que se pode fazer nesse caso é distinguir os preconceitos legítimos dos ilegítimos, colocando-os à prova. O elemento reificado se aproxima dos preconceitos ilegítimos, na medida em que se restringe ou se limita àquilo que perdeu o vínculo com o fluxo da vida. Como bem demonstrou Honneth (2007), essa poderia ser uma atitude observadora, neutra ou desapaixonada frente ao real.

O passo seguinte da interpretação hermenêutica visa buscar o "acordo na coi$s a^{\prime \prime}$, significando esta atitude confrontar a visão do que se tem a partir dos preconceitos com o que está posto no objeto interpretado. E isso pode ser relacionado ao próprio diagnóstico da reificação, se perguntando, por exemplo, até que ponto o intérprete se guia pela ótica do consumo na análise de um produto da publicidade, tomando a imagem como se fosse o objeto, como aduz Jameson. Por último, a hermenêutica procura expressar a ideia da necessidade de deixar que o texto diga algo, o que implica abdicar do que é sabido para se colocar na posição de escuta ou de reconhecimento do sentido comunicado no saber do outro. A confirmação ou não da expectativa inicial de sentido se faz presente nessa ocasião, em que tudo deve confluir para compreender a "fala" do objeto analisado. É claro que isso depende da apropriação dos pressupostos de base da abordagem utilizada, dos instrumentos ou técnicas disponíveis e da competência teórica do intérprete na sua utilização. Nesse sentido, a interpretação hermenêutica não é conflitante com a leitura proposta pela categoria da reificação. De outra maneira, esse conceito pode servir, inclusive, de chave de leitura ou porta de entrada importante para a hermenêutica definir melhor o seu próprio campo de atuação. Afinal, como abordagem metodológica corretiva dos rumos da racionalidade moderna, a hermenêutica guarda, em princípio, forte semelhança com a preocupação expressa nessa categoria, enquanto postura crítica do modo de produção dominante na modernidade. É por isso que, segundo o testemunho de Richard Palmer (2006), algumas obras classificam a filosofia de Marx como uma hermenêutica do social, como é o caso do livro De l'interpretation (1969), em que Paul Ricoeur situa Marx ao lado de Nietzsche e Freud como mestres da suspeita e da desmitificação. Ainda de acordo com Palmer (op. cit., p. 53): “Cada um dos três homens interpretou como falsa a superfície da realidade e avançou com um 
sistema de pensamento que destruiu essa realidade. (...); cada um defendeu uma transformação de pontos de vista, um novo sistema interpretativo do conteúdo manifesto dos nossos mundos - uma nova hermenêutica". Existe então uma dialética entre reificação e formação hermenêutica, entre o mesmo e o outro, que convém ser retomada pela educação, caso ela queira se inserir produtivamente no universo dos processos de estetização.

Pretendo a seguir enunciar algumas pistas, baseando-me na discussão desenvolvida até aqui, que possam permitir esse diálogo entre ambas as categorias.

\section{A educação na dialética do mesmo e do outro}

Apresentei até aqui alguns elementos reflexivos emergentes da categoria de reificação, aproximando-a da ideia de formação, para viabilizar uma leitura dos processos de estetização do mundo da vida. Nesse contexto, a crítica de Lukács aos jornalistas ganha sentido, porque exemplifica o ponto atingido pela materialidade na sociedade contemporânea, na medida em que as próprias faculdades subjetivas do indivíduo se tornaram idênticas à realidade coisificada. Se o caminho para o conhecimento está fechado pela reificação, melhor então perseguir as saídas propostas por diversos autores que pensam essa questão contemporaneamente. Para eles, não é mais possível buscar uma utopia da reconciliação das diferenças no âmbito do puro conhecimento, restando uma investigação no campo da práxis (Honneth), da arte (Adorno) ou do consumo cultural (Jameson). Há neles uma clara tentativa de fugir do tratamento do tema circunscrito ao universo de atuação da racionalidade cognitivista, pois a reificação, na etapa de universalização dos valores de troca da mercadoria, direcionou os padrões culturais para produzir uma sociedade de consumidores.

Para que a educação não recaia na repetência do mesmo, isto é, de algo que não despertou para o novo, situando-se fora do tempo e do espaço históricos, é preciso reconhecer o outro como outro e não como objeto. Retomo neste ponto a ideia defendida por Honneth (2007) de que é preciso se colocar frente à coisificação, caso for pleiteada a sua reversão, não de acordo com a atitude de conhecimento, mas de reconhecimento. Exemplos de negação de reconhecimento não faltam, como as estratégias publicitárias em geral, que desviam a atenção do sujeito para o objeto, do vivo para o morto, do outro para o mesmo. Esta inversão de perspectiva ocorre na medida em que, no ímpeto do consumo, de "administração" do mecanismo psíquico ilusório, o indivíduo acaba tomando a coisa como se ela tivesse vida. Torna-se imperante perguntar que valores são disseminados a esse respeito nesse plano da comunicação? Que tipo de reconhecimento é esquecido nesse âmbito? E, ainda, é possível olhar um objeto fora da dimensão do consumo? Em consequência, torna-se possível 
questionar, igualmente, o papel do "homem/mulher" e do próprio "corpo" exposto nas peças publicitárias: até que ponto são justamente estes os modelos disseminados na sociedade atual? Na verdade, o que está em questão em muitos desses casos é um produto mortificado ou fixado previamente em imagens padronizadas ou reificadas, que se reduplicam rigidamente em formatos e medidas mínimas, independentes dos corpos vivos que as simbolizam ou as exemplificam, sendo este um comportamento típico do contexto mercadológico.

Já um exemplo positivo de reconhecimento do outro é dado no próprio filme Escritores da liberdade. Para atingi-lo, a professora utiliza algumas estratégias e jogos intersubjetivos ao perceber que suas técnicas de ensino tradicionais não estavam dando resultado. Ao se desencadear processos de reconhecimento, os alunos perceberam que havia muito mais coisas a uni-los do que o contrário e que a construção do conhecimento na escola poderia significar também a possibilidade de compreensão das vivências e traçado de perspectivas, enfim, possibilidades de formação humana.

Sendo assim, um caminho produtivo de análise da avalanche dos processos de estetização não passa, obviamente, pela adoção de uma leitura meramente neutra, de indiferença ou, ao contrário, de simples crítica, porque tais iniciativas somente dificultam o diálogo entre culturas diferentes. E isso quer dizer que, por um lado, para o indivíduo viver num mundo reificado pela espetacularização do cotidiano, ele não precisa cultivar relações neutras, desapaixonadas ou de indiferença frente ao que está sendo veiculado. Por outro lado, o presente estado do campo cultural pode representar uma ameaça à formação autêntica, se ele for lido exclusivamente com os óculos do conhecimento. Uma saída desse imbroglio, no qual a própria educação, em certa medida, ficou prisioneira, não está situada, portanto, na preocupação exclusiva com a ideia de formação ou de reificação.

\section{Aspectos conclusivos}

O redirecionamento do comportamento mortificado pode ocorrer por intermédio do papel ativo de participantes que cabe a todos, reavivando assim a dialética do mesmo e do outro. Desse modo, com Honneth (2007) pode se inferir que a redenção das diferenças e da pluralidade se encontra no nível da implicação mútua, isto é, na atitude de reconhecimento (de um plano cultural pelo outro), que serve de base para gerar conhecimentos (menos preconceituosos e mais produtivos sobre o assunto). É nesse sentido que se pode compreender a ideia de que o outro esquecido pela reificação não está "diante dos olhos" simplesmente, pois eles já estão dominados pelo consumo, mas quem sabe muito mais "ao alcance da mão". Essa reflexão pode inspirar uma educação para o uso do controle remoto ou do mouse, não restrita ao 
simples treino de técnicas e habilidades de manuseio, mas para fazer boas escolhas de produtos da publicidade (filmes, livros, jogos, músicas, programas de computador e de televisão, entre outros); e, ainda, prover a participação em cursos/eventos de formação pessoal/profissional e cultural. Certamente, agindo assim os sujeitos estarão se inserindo criativa e produtivamente no universo de expansão do cultural e de estetização do mundo da vida.

Jameson também auxilia a entender a necessidade de mudança dessa mentalidade, porque não se trata de ficar no contraponto de um formato e outro de expressão do campo cultural. Afinal, estas culturas estão presas pelo mesmo traço da materialização que penetrou em profundidade em ambas as formas de expressão. Assim, uma teoria do cultural (Bildung) volta à cena novamente, mas não para ficar aprisionada à interpretação dos grandes clássicos humanistas, exclusivamente. Em outro sentido, a ideia da coisificação, retomada na perspectiva hermenêutica, oferece ainda uma vantagem, desde que essa categoria não seja tencionada fora dos seus limites, isto é, como única via de acesso ao real. ${ }^{4}$

Em consequência, embora admitindo os progressos da formação hermenêutica, frente aos processos de estetização, atualmente não basta a defesa intransigente de uma postura elitista, conceitual, em prol da formação autêntica. Menos ainda a virada populista da imagem, no sentido de contemplar somente os preceitos de industrialização da cultura, enquanto cultura popular, das celebridades ou de massa, com a justificativa de que esse fenômeno está disseminado em nosso cotidiano. Essas posições ainda permanecem no campo meramente epistêmico, isto é, na ideia de classificação, separação ou contradição entre sujeito e objeto, alta e baixa culturas, conhecimento crítico ou alienado, reificação ou formação - o mesmo ou o outro. A via epistemológica é limitada para a compreensão dessas realidades, porque não é pela via do conhecimento, mas do reconhecimento, que se permite ampliar o significado e o alcance do conceito de reificação, tomando-o como um complemento necessário à ideia de formação no sentido hermenêutico. Poder-se-ia dizer que, sem o conceito de reificação no sentido ampliado, a ideia de formação corre o risco de ficar ingênua e inoperante do ponto de vista pedagógico. Ela permite que a formação no sentido hermenêutico assuma uma dimensão crítica. Até porque, no contexto pósmetafísico ${ }^{5}$ não há garantias absolutas do que representa avanço ou retrocesso da humanidade, na medida em que essa visão fica ainda aprisionada a uma concepção linear de filosofia da história.

Se não há seguranças objetivas, é possível diluir estas ambiguidades dizendo que a reificação e a formação são dois lados da mesma moeda (não necessariamente de troca), ou melhor, elas estão particularmente imbricadas. Há uma simbiose, portanto, entre um pensamento preocupado com a alteridade e as diferenças e outro, que chama a atenção para os perigos da repetição do mesmo e do sempre igual, 
do rotineiro e do círculo vicioso. Assim, enquanto a formação hermenêutica serve para recuperar a capacidade do diálogo, a reificação pode advertir sobre os perigos do esquecimento do outro, especialmente quando for tornada impotente a força do diálogo nas vivências pedagógicas.

Uma educação imersa na cultura visual não pode ficar refém dessas aporias, pois uma atitude pura estaria, portanto, fora de propósito, uma vez que não ocorre desenvolvimento de potencialidades humanas sem alguma dose de alienação ou de objetivação do espírito, como Hegel (2008) adverte. Do mesmo modo, nenhum processo de reificação é absoluto, a ponto de cancelar a possibilidade de redenção ou utopia de uma sociedade liberada, conforme expõe Adorno (1993), a partir da arte, e como bem demonstra a reflexão de Jameson (1995) nas análises de filmes. Talvez esse caminho ajude a evitar o equívoco da recusa em assumir uma atitude (ética e estética) de preocupação pelos destinos do mundo comum. Enquanto posicionada de forma distante do campo da formação cultural, ela pode ser indício de influência da própria reificação.

\section{Notas}

1. Filme norte-americano lançado em 2007. Dirigido por Richard La Gravenese e produzido por Danny DeVito, Michael Shamberg e Stacey Scher.

2. A necessidade de contemplar o "elemento morto" nos periódicos não se restringe obviamente às páginas do obituário, ela se dirige para o conjunto da obra, em nome do que está sendo denominado de "estética da barbárie". Segundo Costa (2002, p. 6), "A estética da barbárie, exteriorizada nas manchetes e nos títulos bombásticos, na exclusão de temas socialmente necessários, na exploração do grotesco e do incomum, próprios da cobertura jornalística, difunde-se imperceptivelmente nas técnicas de produção da notícia, em sua conformação aos meios de comunicação e suas linguagens".

3. Cf. o texto: "Porém, reconhecer que a formação é como um elemento do espírito não obriga a vincular-se à filosofia hegeliana do espírito absoluto, do mesmo modo que a percepção da historicidade da consciência não se vincula tampouco à sua própria filosofia da história do mundo" (Gadamer, 1996, p. 44).

4. O equívoco desta situação provavelmente foi originado a partir do próprio tratamento do assunto por Lukács. De um ponto de vista hermenêutico, seria mais aconselhável falar em ideia, conceito ou categoria da reificação, uma vez que o termo "fenômeno" traz um peso cientificista muito forte, dando a impressão de que ele já está posto na realidade e não de que haja aí uma interpretação de algo designado pelo conceito.

5. Enquanto o pensamento metafísico busca explicar a identidade, a origem e a essência de cada ser, através da restrição do múltiplo e da colocação das bases idealistas dos saberes transcendentais, o pós-metafísico indica a superação ou deslocamento do modelo metafísico para um pensamento mais alargado, porém falibilista, no sentido de permitir novas leituras e interpretações de temas e contextos (cf. Habermas, 2002).

\section{Referências}

ADORNO, T.W. Mínima moralia: reflexões a partir da vida danificada. 2. ed. São Paulo: Ática, 1993. 
BOTTOMORE, T. (Ed.). Dicionário do pensamento marxista. Rio de Janeiro: Zahar, 1988.

CHAUI, M. Simulacro e poder: uma análise da mídia. São Paulo: Fundação Perseu Abramo, 2006.

COSTA, B.C.G. Estética da violência: jornalismo e produção de sentidos. Campinas: Autores Associados; Piracicaba: UnIMEP, 2002.

EVANGELISTA, J.E. Elementos para uma crítica da cultura pós-moderna. Revista Pedagógica, Chapeco, v. 10, n. 20, p. 1-24, jan./jun. 2008.

FEATHERSTONE, M. Cultura de consumo e pós-modernismo. Trad. Júlio Assis Simões. São Paulo: Studio Nobel, 1995.

GADAMER, H.-G. Verdad y método II. 2. ed. Salamanca: Sígueme, 1994.

GADAMER, H.-G. Verdad y método I: fundamentos de una hermenéutica filosófica. 6. ed. Salamanca: Sígueme, 1996.

HABERMAS, J. O pensamento pós-metafísico. Trad. Flávio Beno Siebeneichler. Rio de Janeiro: Tempo Brasileiro, 2002.

HEGEL, G.W.F. Fenomenologia do espírito. Trad. Paulo de Menezes. 5. ed. Petrópolis: Vozes; Bragança Paulista: usF, 2008.

HONNETH, A. Reificación: un estudio en la teoría del reconocimiento. Buenos Aires: Kaatz, 2007.

JAMESON, F. Reificação e utopia na cultura de massa. In: JAmeson, F. As marcas do visível. Rio de Janeiro: Graal, 1995. p. 9-35.

LUKÁCS, G. História e consciência de classe: estudos sobre a dialética marxista. Trad. Rodnei Nascimento. São Paulo: Martins Fontes, 2003.

MARX, K. O capital. São Paulo: Abril Cultural, 1983.

MARX, K; ENGELS, F. Manifesto do partido comunista. Petrópolis: Vozes, 1993.

NOBRE, M. Marx teoria do valor-trabalho e fetichismo. In: Nobre, M. (Org.). Curso livre de teoria crítica. Campinas: Papirus, 2008. p. 280-285.

PALMER, R. Hermenêutica. Trad. de Maria Luisa Ribeiro Ferreira. Lisboa: Edições 70, 2006.

RICOEUR, P. Le conflit des interprétations: essais d'herméneutique. Paris: Seuil, 1969. 
WELSCH, W. Estetização e estetização profunda ou: a respeito da atualidade do estético. Revista Porto Arte, Porto Alegre, v. 6, n. 9, p. 7-22, maio 1995.

WELSCH, W. Esporte: visto esteticamente e mesmo como arte? In: Rosenfiel, D. (Org.). Ética e estética. Rio de Janeiro: Zahar, 2001. p. 142-165.

Recebido em 29 de dezembro de 2009.

Aprovado em 11 de agosto de 2010. 